\title{
Agricultural transformations and family farms: some challenges highlighted during the International Year of Family farming
}

\author{
Jean-Michel Sourisseau ${ }^{1 a}$ \\ Marie-Aude Even ${ }^{2 a}$ \\ ${ }^{1}$ CIRAD \\ UMR ART-DEV \\ TA C-113/15 \\ 73, rue Jean-François Breton \\ 34398 Montpellier Cedex 5 \\ France \\ $<$ jean-michel.sourisseau@cirad.fr $>$ \\ ${ }^{2}$ World Agricultures Watch initiative \\ Land and Water Division \\ Food and Agriculture Organization of the \\ United Nations (FAO) \\ Viale delle terme di Caracalla \\ 00153 Rome \\ Italie \\ $<$ MarieAude.Even@fao.org >
}

\footnotetext{
${ }^{\mathrm{a}}$ The views expressed in this information product are those of the author(s) and do not necessarily reflect the views or policies of FAO and other institutions supporting the WAW initiative.

$\mathrm{T}$ he promotors of "the International Year of Family Farming" (IYFF) invited the world to reflect on challenges faced by different farms and their transformations. They aimed at demonstrating to national policy makers the interests of family farming, implicitly compared to other models, notably increasingly industrial agribusiness, whose hegemony, announced by "land grabbing process" and financialization, could be harmful. The term "family farming" is not neutral. International development institutions most often use the concept of "smallholders" to target the most vulnerable. The promotors of the IYFF considered the concept of family farming more inclusive and capable to gather many actors in the North and in the South. The Food and Agriculture Organization of the United Nations (FAO) proposed a broad definition of family farming which was adopted by the multi-stakeholders International Steering Committee of the IYFF: "Family farming is a means of organizing agricultural, forestry, fisheries, pastoral and aquaculture production which is managed and operated by a family and predominantly reliant on family labor, including both women's and men's. Family and farm boldings are often linked, evolve together and fulfill economic, environmental, social and cultural functions" (FAO, 2014). Such definition emphasizes the links between productive and domestic sphere and considers that family farms are not only producers of raw material, but first and foremost social actors. Beyond the apparent consensus, disagreements remained. Some actors considered that the concept could include farms engaged in modernization and artificialization process, and preferred the term of "peasant farms". While some find the limits of waged labor too restrictive, others would like to totally exclude the use of permanent waged labor. Finally, others pointed the need for a more operational definition, with criteria available from public statistics and stricter thresholds, so as to accurately measure the contributions of family farms with available data. The focalization of discussions on such definition finally refers to wider debates on transformations of agriculture and needs for inflexions of future development, considering rapid changes faced since the 60s, limits of current models, and questions over land grabbing and financialization trends. To inform such debate, improved studies, data and monitoring systems are needed with an important role for research.

Research can first shed light on what is tied within family farms, and develop methods to identify and characterize performance of farms, with objective and relevant criteria. Better defining family farms is a necessary basis for building and implementing appropriate 
and targeted public policies. Much work was done in such area. Various criteria were proposed to differentiate forms of production: share of family labor, nature of the links between productive and domestic sphere, farm size, degree of market integration, property of means of production, residence of operators and anchorage in rural community, dependence on upstream and downstream actors, diversification of production and activities, and operational management of farms. No consensus was reached, with difficulties related to diversity of contexts, actors, data, heterogeneity of family farms, and purpose of definitions. Such work also raised the need to provide a typology of family farms to better understand their internal diversity. It also highlighted that many criteria are difficult to quantify and cannot be filled with available statistical data. The World Agricultures Watch initiative (WAW - http://www.worldagricultureswatch.org/) started working on such topic with its partners. An international working group was set up by the IYFF to further work on such issues. FAO will continue to animate similar work with WAW and the global strategy for improved agricultural and rural statistics (GSARS), trying to combine statistical and global requirements with more comprehensive and local approaches, including different stakeholders, to effectively contribute to agricultural policies.

Research can also help better document and monitor in agriculture, comparing strengths and weaknesses of family and non-family farms (Sourisseau et al., 2015), analyzing possible risk and prospects for their coexistence. Convergence of forms of production and their selection according to their competitiveness often appears as a foregone conclusion. By highlighting ongoing dynamics and diversity of possible trajectories of transformations, research can facilitate more informed policies, which are once again considered as key determinants of development processes.

This special issue of Cabiers Agricultures contributes to such post-IYFF agenda. It also continues the work initiated in 2008 by the World Agricultures Watch initiative and builds on an international seminar organized during the 10th Symposium of International Farming
System Association (http://www.worldagricultureswatch.org/events/july-201210th-ifsa-symposium).

Change processes are often analyzed at macro level. On the contrary, this special issue proposes to consider the diversity of local and global processes of agricultural transformations, the roles of public policies and their impacts on diverse family farms, with contrasting case studies.

A first overview article (Bosc and Bélières, 2015) compares global and macroeconomic approaches with micro-economic approaches of agricultural holdings, to understand the nature and diversity of agricultural transformations. It highlights the risks of stereotypical and aggregated visions. The first two case studies focus on two iconic drivers of change: urbanization (Parrot, 2015) and "land grabbing" (Burnod and Medernach, 2015). Parrot analyzes the transformation of a small town in Cameroon, highlighting the uniqueness and variety of urban forms and their impacts, discussing risks and opportunities for family farms. Burnod and Medernach jostle our assumptions about large-scale land acquisitions in Madagascar. They show that the entrepreneurial forms struggle to deploy, while relations with family farms are neither necessarily conflicting nor negative.

The following articles compare national development agenda with resistances or adaptations of farms targeted by such transformations. National plans focus on productivity, including size increase, specialization and market integration, common keywords of agricultural development. Small family farms, also poorly defined, are often stigmatized for their low productivity. The case studies in Canada (Machum, 2015) and Sierra Leone (Saravia-Matus and Gomez y Paloma, 2015) illustrate how such public policies, because they underestimate the implications for the families and the territories concerned, encounter resistances which lead to new trajectories of change. It also shows how statistical data can underestimate non-profit sector and smallest farms. National plans may also refer to environmental norms. Representations of livestock farmers on technical options to reduce deforestation in the Brazilian Amazon (Cialdella et al., 2015) illustrate at the same time the rapid development capabilities of family and non-family systems, but also a certain inertia related to the social (and often risky) implications of the technical changes promoted.

Finally, the articles illustrate a diversity of transformations of farms which are also diverse. They show the role of policies and context in shaping these trajectories. Different individual and collective coping strategies are described. They demonstrate the need to take into account, altogether, the dynamics of transformations, the diversity of contexts, and the diversity of farms coexisting in the same territory. Analyzing the characteristics of such diversities and the views of different actors appears fundamental to better understand the challenges to implement promoted changes, and to argue the participation of actors in policy dialogue.

\section{Références}

Bosc PM, Bélières JF, 2015. Transformations agricoles : un point de vue renouvelé par une mise en perspective d'approches macro et micro-économiques. Cahiers Agricultures 24:206-14. doi: 10.1684/agr.2015.0762

Burnod P, Medernach K, 2015. Interrelations entre agro-industrie et agricultures familiales vues par le prisme du système agraire. Cahiers Agricultures 24:224-31. doi: 10.1684/agr.2015. 0758

Cialdella N, 2015. Do political changes aimed at reducing Amazonian deforestation contribute to ecological intensification? Cahiers Agricultures 24: 246-54. doi: 10.1684/agr.2015.0761

FAO, 2014. Legacy of IYFF 2014 and the way forward. Rome: Food and Agriculture Organization of the United Nations. http://wwww.fao.org/3/bmm296e.pdf

Machum S, 2015. Shifting practices and shifting discourses: policy and small-scale agriculture in Canada. Cahiers Agricultures 24:232-9. doi: 10.1684/agr.2015.0756

Parrot L, Nantchouang A, Dongmo C, 2015. Les transformations de I'agriculture familiale dans les petites villes : le cas de Muea au Cameroun. Cahiers Agricultures 24:215-23. doi: 10.1684/agr.2015. 0759

Saravia-Matus S, Gomez y Paloma S, 2015. Challenges in implementing the National Sustainable Agriculture Development Plan (NSADP) for subsistence and semisubsistence farmers in Sierra Leone. Cahiers Agricultures 24:240-5. doi: 10.1684/agr. 2015.0757

Sourisseau JM, Kahane R, Fabre P, Hubert B, 2015. Actes des Rencontres internationales. Montpellier, France, 1-3 juin 2014. Montpellier: Agropolis international. http://www.agropolis.fr/pdf/publications/actes-rencontres-internationales-agriculturesfamiliales-recherche-juin-2014.pdf 